\title{
Paternalist Economic Policies: Foundations, Options, and Challenges
}

\author{
Rainer Klump and Manuel Wörsdörfer ${ }^{1}$
}

\begin{abstract}
This paper analyzes the inherent dangers of paternalist economic policies associated with the newly established economic sub-disciplines of behavioral economics, economic happiness research and economic psychology. While the authors in general welcome these sub-disciplines for enriching and critically evaluating mainstream economics - especially their criticism of the Homo oeconomicus-heuristic is of great value contributing to a more realistic idea of man -, the political-economic implications as well as inherent risks of paternalist economic policies should be received with concern and thus be subject to a critical review. The paper is structured as follows: In the first step, we recapitulate Kahneman's, Thaler/Sunstein's, and Layard's versions of paternalism pointing at similarities and differences alike. We contrast libertarian or soft paternalism of behavioral economics (Thaler/Sunstein) and economic psychology (Kahneman) with (Layard's) happiness economics and its hard paternalism. In the second step, we analyze the political and economic implications and consequences of paternalism. We give an overview of the main points of criticism of paternalism from a constitutional economics perspective. The Ordnungs- vs. Prozesspolitik argument is discussed as well as epistemological, political-economic or idea of man arguments. The paper ends with some concluding remarks.
\end{abstract} Keywords: Libertarian/Soft Paternalism; Constitutional Economics; D. Kahneman; R. Thaler; R. Layard. JEL Classification: B25, B5, D02, D03, D87, P16, P48, Z1.

\section{Introductory Remarks}

\author{
"... behavioral economics [economic \\ psychology, and some forms of happiness \\ research] will contribute to the foundation \\ of the new paternalistic state." \\ “... by becoming behavioral, economics \\ is no longer capable of providing an \\ intellectual safeguard against excess \\ government intrusion in private matter" \\ (both: Saint-Paul 2011: p. 4/97)
}

Paternalism has been known for long as a specific type of practicing policy generally criticized by liberal economists of lacking sound scientific justifications (cp. Saint-Paul 2011). In recent years, however, this assessment seems no longer valid, since paternalism visibly gains ground: Different variations of paternalism have become a recommended concept in the theory of economic policy driven by and intrinsically related to recent advances in economic theory: First, Daniel Kahneman, one of the main representatives of economic psychology and winner of the Nobel Memorial Prize in Economics, favors soft paternalism, a particular type of soft state interventionism that nudges people to make the right decisions which will serve

\footnotetext{
${ }^{1}$ Address for correspondence: Rainer Klump, Chair of Economic Development and Integration and Cluster of Excellence 'The Formation of Normative Orders', Goethe University Frankfurt, Grueneburgplatz 1, 60323 Frankfurt am Main; E-Mail: klump@wiwi.uni-frankfurt.de. Manuel Wörsdörfer, Cluster of Excellence 'The Formation of Normative Orders', Goethe University Frankfurt, Grueneburgplatz 1, 60323 Frankfurt am Main; Phone: +49 (0)69-798-34782; Fax:+49 (0)69-798-35015; E-mail: woersdoerfer@wiwi.uni-frankfurt.de.
} 
their own long-term interests. In his recent bestseller Thinking, Fast and Slow (2011), Kahneman elaborates the concept of soft paternalism in great detail, frequently referring to the work of the behavioral economist Richard H. Thaler. Second, in the book Nudge. Improving Decisions about Health, Wealth, and Happiness (2008/2009), Thaler and his coauthor Cass R. Sunstein, once an influential economic advisor to the Obama administration ${ }^{2}$, speak of libertarian paternalism which is similar to Kahneman's interpretation of paternalism. Finally, the British economist Richard Layard is deriving a specific type of hard paternalism from economic happiness research, indicating a way that goes far beyond liberal economics.

The reason for choosing these three 'new economics'-approaches ${ }^{3}$ - Kahneman's soft paternalism, Thaler/Sunstein's libertarian paternalism as well as Layard's hard paternalism is that they represent three different kinds of economic sub-disciplines - namely economic psychology, behavioral economics and economic happiness research - which have been gaining momentum in recent years. All three sub-disciplines are in major respects deviating from mainstream economic theory aiming to establish a new economic paradigm for the theory of economic policy with far-reaching consequences.

The following paper aims at making explicit the inherent dangers and risks of paternalist economic policies associated with these newly established economic sub-disciplines. While the authors in general welcome these new strands of research for enriching and critically

\footnotetext{
${ }^{2}$ From 2009 to 2012, Sunstein served as the administrator of the White House Office of Information and Regulatory Affairs (OIRA).

${ }^{3}$ Further concepts of paternalism are introduced by O'Donoghue and Rabin (2003), focusing on the optimal (amount of) paternalism, and by the behavioral economist Colin Camerer and colleagues (Camerer et al. (2003)) opening up the 'case' for asymmetric or conservative paternalism. Camerer's et al. argument goes as follows: Recent research in behavioural economics has identified a variety of cognitive shortcuts and decision-making anomalies (including lack of will-power and self-control problems) that are inconsistent with utility maximization and, thus, depart from rational choice theory. These errors prevent people to behave in their own best interest. As such, paternalistic policies and regulations restrict consumer sovereignty by forcing or preventing choices for the individual's own good; they are designed to prevent or overcome these decisionmaking anomalies. A state regulation is asymmetrically paternalistic if it creates large advantageous for those people who are boundedly rational and, therefore, make cognitive errors, while at the same time imposing little or no harm on those who are fully rational. Such policies are relatively harmless to those who reliably make choices in their best interest, while beneficiary to those making suboptimal decisions. The costs for rational actors are minimized while the benefits to boundedly rational actors are maximized. The authors distinguish four types of asymmetric paternalistic policies (default rules, provision or re-framing of information, cooling-off periods, and limiting consumer choices) that apply mainly in the fields of health and food regulations as well as consumer protection. Finally, Loewenstein and Haisley speak in their paper 'The Economist as Therapist' of light paternalism which is contrasted with 'heavy-handed' paternalism: The goal of this approach is "... to steer human behavior in more beneficial directions while minimizing coercion, maintaining individual autonomy, and maximizing choice to the greatest extent possible. Light paternalism aims to enhance decision making without restricting it" (Loewenstein/Haisley 2008: pp. 212). Behavioral economics is defined here as a new form of normative economics and light paternalism as a growth industry within economics.
} 
evaluating standard economics - especially their criticism of the Homo-oeconomicus heuristic is of great value contributing to a more realistic idea of man -, the political-economic implications as well as inherent risks of paternalist economic policies should be received with caution and thus be subjected to a critical review. ${ }^{4}$

The following research questions are addressed by the paper in particular: What are the epistemological implications and consequences of paternalism in terms of economic theory? Is paternalism necessarily accompanied by or respectively associated with 'illiberalism', a violation or restriction of personal freedom, and a benevolent dictator state? Is it after all possible to limit paternalism to a clearly defined and restricted area of social or public policy? Is there a slippery slope argument involved as it is traditionally put forward against all forms of state interventionism following the classical analysis by von Mises (cp. Mises 1922; 1927) and Hayek (cp. Hayek 1944/2007) stating that once paternalism is applied and practiced, we will steadily move from a liberal towards an authoritarian society in which people are deprived of their rights of decisions? These kinds of questions are closely related to the underlying different ideas of man: Is a paternalist theory of economic policy consistent with a liberal and autonomous (in the Kantian sense of the word) idea of man including human dignity and individual as well as social responsibility?

The remainder of this paper is structured as follows: In the first step, we recapitulate Kahneman's, Thaler/Sunstein's, and Layard's versions of paternalism pointing at similarities and differences alike. We contrast libertarian or soft paternalism of behavioral economics (Thaler/Sunstein) and economic psychology (Kahneman) with (Layard's) happiness economics and its hard paternalism. In the second step, we analyze the political economic implications and consequences of paternalism. We give an overview of the main points of criticisms of paternalism from a constitutional economics perspective. The Ordnungs- vs. Prozesspolitik argument is discussed as well as epistemological, political-economic or idea of man arguments, to name just a few. The paper ends with some concluding remarks.

\footnotetext{
${ }^{4}$ Here, the authors of this paper deviate from Saint-Paul (2011) in several regards: First, Saint-Paul seems to be an advocate of the neoclassical approach in economics including a defense of laissez faire, the minimal state, negative liberty rights, as well as the Homo oeconomicus conception; second, he radically dismisses behavioral economics and economic happiness research in general (without adequately differentiating between the different perspectives); third, he seems to be unaware of alternative, more constitutional economics oriented approaches also originating from 'new economics'.
} 


\section{Soft or Libertarian Paternalism}

\subsection{The 'Nudge' Approach}

Nowadays, different versions of paternalism exist. In general, we can draw a dual distinction between libertarian and soft paternalism of behavioral economics and economic psychology on the one hand and hard or strong paternalism of (Layard's) happiness economics on the other hand. First, let us have a closer look at Thaler/Sunstein's concept of libertarian paternalism (cp. Thaler/Sunstein 2003a; 2003b; 2008/2009; Sunstein 2013a and $b^{5}$ ). The overall aim of Thaler/Sunstein is to (re-) organize the context in which individual decisions are made. All that counts is the (framing) choice architecture. Some situations require a push in the 'right' direction, or as Thaler/ Sunstein call it, they need a nudge. The reason why Thaler/Sunstein speak of libertarian paternalism is that their approach tries to combine liberal as well as paternalistic elements ${ }^{6}$. The 'libertarian' elements refer to the aim of conserving and ideally increasing individual freedom and autonomy of choice by adequate policy guidelines. People should be free to do what they really want and to opt-out of undesirable options in case that they want to do so. The paternalistic element on the contrary refers to choice architects in influencing and steering people's decisions (and behavior) into the 'right' direction (once it has been recognized as such). According to Thaler/Sunstein, their version of paternalism is a well-intentioned, thoughtful and a caring one, an approach that does not restrict the available options or rule out any possibilities. It does not impose sanctions, prohibitions, or severe restrictions; there are simply no binding and mandatory dos and don'ts. Thaler/Sunstein's form of paternalism has its most significant effects in the fields of investments, pension plans, organ donation and health care. Typical objectives of paternalist interventions by nudges are to enlarge life expectancy, increase personal well-being or improve health conditions. In all mentioned fields, the overall aim is to create a user-friendly framing and to re-design the architecture or setting in which choices are to be made. The basic principles for a good choice architecture, as Thaler/Sunstein (2008/2009: chapter 5) call it, include the following ones: 1 . Socially desirable standard defaults: Since ordinary users are cognitively lazy, they will usually maintain the standard factory settings; 2. fault tolerance: Errors and mistakes are natural and occur often, so the socio-economic and political system

\footnotetext{
${ }^{5}$ See also Carlin et al. 2009; Altman 2012: p. 13/146/297/307, pp. 311 and chapter 5.

${ }^{6}$ Libertarianism and paternalism: It is unapparent how to combine these contradictory political ideologies. Indeed, when consulting the work of some truly libertarian thinkers such as Murray N. Rothbard (anarchocapitalism; cp. Rothbard 1962/2010; 1982/2003) and Robert Nozick (minimal state; cp. Nozick 1991), the differences come to light. Their conceptions of the state differ sharply from soft/libertarian paternalism, let alone hard paternalism.
} 
should accept and allow for them; 3. feedback mechanism: The implementation of regular feedback processes is essential in order to inform people about their mistakes and how they could improve their decisions and actual behavior; 4. mapping: Decision makers have to be supported to choose options that fit their own interests best. It is essential to provide edited and generally intelligible information relevant for decision making; 5. transparency: Disclosure, publication and comprehensibility/understandability of all relevant information is further required. It has to be structured, edited and in some sense even simplified for the end user so that complex decisions are manageable.

\subsection{Foundations in Economic Psychology and Behavioral Economics 7}

The parallels to and from Kahneman's works are astonishing; both research agendas complement each other: Kahneman speaks of soft paternalism, while Thaler/Sunstein speak of libertarian paternalism. In addition, Kahneman refers to Thaler's distinction between 'Econs' and 'Humans' (cp. Kahneman 2011: p. 269/p. 277/pp. 411), while Thaler/Sunstein in turn refer to Kahneman's and Tversky's work on cognitive fallacies, heuristics and biases. ${ }^{8}$

Kahneman's work is well-known for its distinction between two different kinds of reasoning: an intuitive and automatic one (System 1), and a reflective, rational and deliberating one (System 2). The automatic and intuitive system works uncontrolled, effortless, fast, unconscious and in an associative way. The reflective system instead works controlled, effortful, slowly, self-conscious, rule-governed and in a deductive way. In short: Gut feelings and instincts face rational thinking. ${ }^{9}$

Rules of thumb or heuristics are essential in dealing with everyday complexity. They help to reduce complexity in an overly complex world; but at the same time, they are often the main cause for systematic cognitive errors. The most often discussed judgment heuristics are the anchor heuristic, the availability heuristic, and the representativeness heuristic (cp. Kahneman 2011). The heuristics and biases approach by Kahneman and Tversky highlights the important role of stereotypes, clichés as well as chance and coincidence. Incidences that happen by chance are often interpreted in terms of causal patterns. Other sources of systematic errors and cognitive biases include unrealistic optimism (accompanied by cognitive dissonance (cp. Akerlof/Dickens 1982)) and overconfidence - often leading towards excessive risk-taking.

\footnotetext{
${ }^{7}$ Since the concepts of soft and libertarian paternalism are closely related and their respective representatives explicitly refer to each other, we use both terms synonymously in the upcoming paragraphs.

${ }^{8} \mathrm{Cp}$. for more information on the heuristics and biases approach: Kahneman/Tversky 1972; 1974; 1979; 1984; 1986; 1996; Tversky/Kahneman 1971; 1980; 1983; 1992; see also Altman 2012: pp. 133.

${ }^{9}$ Cp. Kahneman 2011: pp. 20; see for a similar distinction between intuitive system and reasoning system: Haidt 2001: p. 818 .
} 
The above-average effect is a good example illustrating overconfidence in practice. ${ }^{10}$ Loss aversion (cp. Altman 2012: pp. 122) is a further phenomenon discussed by Kahneman, Tversky, Thaler and Sunstein. It incorporates inertia, idleness, and procrastination as well as the preservation and protection of vested rights. Cognitive idleness and inertia also play a major role in the status quo bias (cp. Samuelson/Zeckhauser 1988): Most people tend to preserve the current situation; they hold on and stick to the status quo (which implies a certain type of conservatism as well as traditionalism). As a consequence, people often forfeit chances and miss good opportunities. Last not least, framing or context effects ${ }^{11}$ also reflect the bounded rationality ${ }^{12}$ of humans: the outcome often depends on the way the situation is presented, the question is asked, the information is conveyed or the available options are presented.

All previously mentioned effects analyzed by Kahneman and Tversky point to the human fallibility caused by the cognitive limitations and bounded rationality of human beings on the one side (i.e., limited abilities to acquire and process information) and by the complexity of today's world on the other side. Another reason why individual decisions contain many systematic errors and cognitive illusions is their particular social context: Individual's decisions are heavily shaped by the actions (and decisions) of others. Pluralistic ignorance and the tendency towards conformism (i.e., group judgments and collective decisions) might lead to collective conservatism and preservation of old habits, traditions, and shared mental models. The felt social or peer pressure often leads to assimilation to social norms and the feeling to necessarily meet required social standards. The power of social influence might lead to an imitation and mimicking of other's behavior ending into a collectively selfinjurious herd behavior. Not least, the economic and financial crises in the recent years have shown the dire consequences of speculative bubbles as a consequence of herd mentality on financial markets and its inherent contagion effects. Emotions such as euphoria in boom phases as well as fear and mistrust in bust periods can have significant effects. Keynes (1936/1973) and Akerlof and Shiller (2009/2010) speak of 'animal spirits' that dominate human behavior.

\footnotetext{
${ }^{10}$ Malmendier et al. have analyzed the role of overconfidence and its effect on CEO-decision making: $\mathrm{cp}$. Malmendier/Tate 2005a; 2005b; 2008; 2009; Malmendier/Guner/Tate 2008.

${ }^{11}$ Cp. Kahneman 2011: p. 272; Altman 2012: pp. 131.

${ }^{12}$ Cp. Simon 1957; 1959; 1990; 1991: The main cognitive biases discussed by behavioral economics include cognitive dissonance (e.g., availability bias), time inconsistency (consumption choices: consuming now vs. in the future), mental budgeting, intrinsic motivation, context effects (i.e., framing, loss aversion, endowment effect, habit formation), and confidence-enhanced performance. They all have one aspect in common: they represent violations of rationality and deviate from the predictions of standard economic theory (cp. Saint-Paul 2011).
} 
As a consequence, Thaler/Sunstein - in complete accordance with Kahneman (and Tversky) are highly critical of the mainstream economic view of man, the Homo oeconomicus, or as Thaler puts it: Econs. Unlike Econs, Humans make lots of systematic mistakes because of their cognitive fallacies and their reliance on heuristics, but also because they are highly influenced by the social setting and social interactions. Human reasoning is mainly characterized by inertia and dullness, cognitive biases and errors (due to cognitive limitations and constraints often referred to as bounded rationality). Consequently, 'Humanworld', the world of the Homo sapiens, is fundamentally different from 'Econworld', the world of the Econs: Econs of standard economic theory rely highly on rationality; they are commonly described as hyper-rational, unemotional, and self-interested utility maximizers with stable and consistent preferences. Humans, to the contrary, are de facto boundedly rational actors. Unlike Econs who solely rely on System 2, Humans possess both Systems 1 and 2 (cp. Kahneman 2011: p. 277). Their decision-making capabilities are cognitively limited due to the omnipresence and dominance of System 1, and the laziness of System 2; they are by far not as rationally consistent and logical as the ones of Econs. Moreover, they are not narrowly selfish and egoistic (instead, social preferences and pro-social behavior play a huge role) and their decisions are shaped by social context, culture, history (past decisions), social relationships as well as emotions, passions, affects, and intuitions.

\subsection{Consequences for Economic Policy}

In a nation full of Econs and rational Homo oeconomicus-agents, politics and government should refrain from intervening into markets. They should rather keep out of the way allowing Econs to act as they want to as long as they do not harm others. However, in a (real) world full of Humans, government has a prominent role to fulfill, a role that exceeds the function of the state as libertarian or laissez faire night watchman state. State and other public institutions are required to nudge people to make the right decisions that serve their own long-term interests. Contrary to Econs, Humans need protection by the state; otherwise their weaknesses would be exploited by others and harm would arise. In soft or libertarian paternalism, the state is a major tool in helping people to overcome their cognitive biases and systematic errors; the state ideally helps people to prevent the adverse consequences and effects of boundedly rational behavior. ${ }^{13}$

\footnotetext{
${ }^{13}$ Kahneman, Thaler and Sunstein seem to assume that politicians as well as their policy advisors - unlike ordinary people - are free of systematic cognitive errors and bounded rationality (cp. the epistemological argument presented in chapter 4).
} 
Moreover, the state has to fulfil a further task: As we have seen, Humans are described as being cognitively lazy. As such, they are reluctant to change once well-established attitudes and customs settings according to the motto: old habits die hard. It takes some effort to bring oneself to change almost unbreakable habits. One way to break or change these habits would be by force, coercion or authoritarian orders. Kahneman, Thaler and Sunstein, however, are convinced that small, little 'nudges' by the state are the better way to overcome the just mentioned cognitive biases resulting in structural conservatism. Furthermore, nudges can pave the way towards achieving public goods: They channel behavior into socially desirable canals (once they are identified) ${ }^{14}$ and help to promote the common good, e.g., in the form of an increase of the saving rate, a better health care system, an increase in the number of organ donations or environmental protection.

From a liberal perspective, soft or libertarian paternalism is preferable to hard paternalism with its illiberal commands, orders, bans and prohibitions; it tries to avoid authoritarian coercion and compulsion, and makes use of economic incentive structures, e.g. in the form of (impersonal or personalized) default rules (cp. Sunstein 2013c). Given the complexity of everyday-life and human bounded rationality, people are looking out for help (in order to reduce complexity and cognitive limitations to a minimum); they are sensitive and susceptible to nudges. With the help of adequate standard settings and defaults provided by public authorities (nudges), it becomes feasible for ordinary people to deal with these complexities.

Thaler/Sunstein's approach assumes that social and emotional nudges are preferably applied in a sparing, efficient, and purposeful way. Positive nudges in the right direction make sense in the public as well as in the private sphere. The golden rule of libertarian paternalism is: the state and other eligible public institutions should apply those kinds of nudges that most likely help people making better decisions, and at the same time, avoid those nudges that potentially harm others. ${ }^{15}$ Soft or libertarian paternalism assumes that people need small, little nudges when they face difficult, complex and unique situations, when they do not receive proper and immediate feedback information, and when they do not grasp all relevant aspects of the

\footnotetext{
${ }^{14}$ But what does it mean to speak of 'socially desirable goals' or common/public goods? How do we identify them and how can they best be achieved? Which measures should be adopted? How can we channel behavior in a most efficient way? Who are the persons in charge making these decisions? How can we best deal with errorproneness and the danger of government failure? These and other questions will be at the heart of chapter 4 .

${ }^{15}$ Again, we need to ask: How do we know what kind of decisions will make people better off and how do we avoid decisions harming others? Where does that knowledge come from and which institution can provide all the required information (cp. epistemological/elitist-expertocratic argument in chapter 4.3)? Even more important: How can we ensure to avoid the inherent dangers of abuse (of power) and manipulation (cp. the politicoeconomic argument in chapter 4.2.)? How is it possible to prevent a nanny state and a benevolent dictatorship? Which precautionary measures should be adopted (cp. the nanny-state/slippery slope argument in chapter 4)?
} 
decision making process. Here, the state can help providing information relevant for decision making and improving feedback mechanisms. Thaler/Sunstein state that competitive markets and its incentive structures are an indispensable tool: Well-functioning markets can compensate and relativize the cognitive weaknesses of human beings ${ }^{16}$; competition can protect irrational customers and improve their decision-making. In some cases, however, competitive markets need to be complemented by soft state interventionism in the form of nudges - and this argument goes beyond the classical cases of market failures. From the perspective of behavioral economics, market failures are broadly defined not only taking (negative) externalities, asymmetric information, market power and public goods into account, but also incorporating cognitive errors and biases as a further(!) category of market failure. ${ }^{17}$ In our view, the behavioral economics concept of market failures goes far beyond the narrow definition of traditional economics opening the floodgates for a new form of corrective state interventionism.

Before turning to a fundamental critique of paternalism, let us take a closer look at Layard's research program which explicitly and positively refers to the libertarian paternalism concept (cp. Layard 2005/2011: p. 271). Here, the paternalistic tendencies are even more pronounced than in Thaler/Sunstein's and Kahneman's approach and the inherent dangers manifest themselves and become much more visible.

\section{Hard Paternalism}

\subsection{The 'Greatest Happiness Principle'}

Layard's happiness economics stands in the tradition of Benthamite utilitarian philosophy, although he aims at a modern version and a slightly modification of classical utilitarianism. The centre of his concept is the 'Greatest Happiness Principle' according to which "[ $t]$ he common good consists in the happiness of all. The good society is one where people are as happy as possible, and as few as possible are miserable. The right action (and the right policy) is the one that produces the greatest happiness and, especially, the least misery" (Layard 2010: p. 27; 2005/2011). The best society, according to Layard, is the one where citizens are the happiest, the right moral action or the best private behavior is that which produces the

\footnotetext{
${ }^{16}$ The basic question is whether or not competitive markets are best able to condense information and reduce complexity? In case that the answer is negative, the demand for paternalistic interventionism will increase.

${ }^{17}$ In a recent article and in his latest book, Sunstein speaks of 'behavioral market failure' as a supplement to the standard accounts of market failure providing new grounds for government action (cp. Sunstein 2013b: pp. 72). These kinds of market failure justify 'means paternalism' (as opposed to 'end paternalism') (cp. Sunstein 2013a: pp. 6/pp. 23; 2013b: pp. 192). Means paternalism is equivalent to the 'regulatory moneyball' of the nudge approach and libertarian paternalism.
} 
most happiness for the people it affects, and the best public policy is the one which produces the greatest happiness of all. Layard's happiness concept is holistic and egalitarian in the sense that it takes the happiness of all into account and that everybody's happiness is to count equally; at the same time, it is humane in the sense that what matters is what people feel. Happiness, therefore, is described as a feeling - although an objective one. The objective dimension of happiness refers to the fact that happiness as an individual (and social) experience is (neuro-)scientifically measurable - pointing at the linkage between economic happiness research and neuroeconomics. According to Layard, public policy as well as private behavior should be committed to promote happiness as THE ultimate common good in a society. As such, public policy must be judged by how it fosters human happiness respectively reduces human misery and unhappiness.

\subsection{Foundations in Economic Happiness Research}

Economic happiness research ${ }^{18}$ has shown that, although living standards have risen so sharply in most industrialised countries, the level of happiness has not increased in the last couple of decades. This result is often referred to as the Easterlin Paradox, named after one of the 'fathers' of economic happiness research, Richard Easterlin. Easterlin (1995) found out that extra income is only valuable when it lifts people away from sheer physical poverty and raise them above the minimum existence level. As such, extra happiness provided by additional income is greatest when people are poor, yet it declines steadily as people get richer. As a consequence, the effect of extra income on happiness is greatest in poorest countries. In rich countries, however, there is almost no improvement in happiness: people do not report themselves as happier over time.

What might be the reasons for this - at first sight - paradoxical result? First of all, the actual level of happiness that an individual perceives is not only related to its absolute income. What counts even more are the relative income as well as the perceived relative position in society. Moreover, the income aspirations and expectations are essential: people are quite often even willing to accept a significant decrease in living standards if they could move up on the social ladder. Consequently, the level of happiness depends much more on what other individuals get and what a person is used to get - pointing at the high importance of social comparisons and habituation alike. In case that the actual income rises, the expectations and aspirations are raising likewise: the norm by which income is judged rises as much as the pay rises. In recent

\footnotetext{
${ }^{18}$ Cp. for a general overview: Frey 2010; Frey/Frey Marti 2010; Weimann et al. 2012.
} 
decades, individual's norms have adjusted rapidly to the actual living standards (which makes an increase in happiness even more unlikely). Furthermore, a pay rise is in some cases related to an upward change in reference group, which might cause misery as well. Interestingly enough, humans tend to compare themselves to people that are up in the social hierarchy, not to people that rank lower. This, too, seriously affects the perceived happiness of people. ${ }^{19}$

A further reason for the lack of improvement in the level of happiness in most industrialised countries is the 'hedonic treadmill' problem: According to Layard and others (cp. Layard 2005/2011), distorted incentives and negative externalities are ubiquitous in our societies: people have to keep running just in order to preserve their perceived level of happiness. Even worse, for a person working harder and raising her income, she might be blamed for making others less happy. As a consequence, everyone is working harder and harder (i.e., working overtime). In total, there are incentives in the market society to work more than is socially efficient and beneficiary (this kind of pollution or negative externality is not taken into account both by politics and individuals). The problem is that this self-defeating status race is a zero-sum game: the gain of one person is the loss of another. In other words: the social advancement of one person is the downward social movement of another (in relative positions). Layard blames our society for this rat or arms race leading into a distorted worklife-balance. Moreover, he criticizes the prevalent consumerism and increasing materialism in industrialised societies. He speaks of an overinvestment in material goods at the expense of leisure time (here again, we are facing the problem of a distorted work-life balance). According to him, living standards are to some extent like drugs: people get easily addicted to income and material possessions. They adapt quickly to the material status quo, get used to it, and after a while, they are dissatisfied with what they currently have and demand more. This process of ongoing adaptation and habituation is often neglected. From Layard's perspective, all previously mentioned negative externalities and distorted incentives need to be corrected by the state. We will return to this legitimization of further state interventionism later on in this chapter.

Before that, we have to explore the determinants of human happiness: According to Layard, human happiness rests on seven factors, often referred to as 'The Big Seven' (cp. Layard 2005/2011: pp. 62): family relationships, financial situation, work/working conditions,

\footnotetext{
${ }^{19}$ The minor increase in pecuniary life-satisfaction stems from the fact that people are comparing their material incomes with what others like them are getting or with what they themselves have got used to. Consequently, big rises in upper income groups bring so little extra happiness.
} 
community and friends, health, personal freedom ${ }^{20}$ and values. ${ }^{21}$ Satisfaction with personal and community life (family, marriage and friendships, social networks), financial satisfaction, satisfaction with work, good health and political freedom - all these factors contribute to a happy life.

When taking a closer look at the sources of happiness, it becomes obvious (according to Layard et al.) that some of them have improved tremendously in the last couple of decades, especially the overall health conditions as well as the level of income and the quality of work. But some of the factors have deteriorated; here, we have to refer to the alleged worsening of family and community relationships as well as the (alleged) rising of selfishness and egotism. These adverse trends manifest themselves in an ever increasing number of broken families (i.e., divorces and families headed by a single parent), substantially more pressure at work, less cohesive communities, increasing trends in depression, alcoholism and crime, as well as a far-reaching decline in trust and social capital (i.e., fewer and fewer people in Western countries are members of clubs and associations ${ }^{22}$ ).

Following Layard (2005/2011), all these adverse trends imply a profound change in attitudes to the self and society, a fundamental change for the worse since morals and the level of trust are constantly declining. Layard blames the growing culture of rampant individualism, the upward trend in egoism and selfishness, and the rise of reckless materialism for the decline of community life and the lack of fellow-feeling, solidarity and social responsibility. His social criticism (Gesellschaftskritik) and in some sense structural conservatism become obvious when he states that the spread of television, the increasing geographical mobility in a globalised world economy, and the change in gender roles are accountable for the change in values, and when he bemoans the decline in religious belief; the old religious and sociocultural norms and sanctions are gone leaving decadence, nihilism, and a moral vacuum.

\footnotetext{
${ }^{20}$ Here, the following aspects are essential: political stability, lack of violence, rule of law, absence of corruption, effectiveness of government services, efficiency of the system of regulation, personal, political and economic freedom, and last not least, voice and accountability. The latter point bears some remarkable resemblances to the work of Frey et al. (cp. Frey 2010; Frey/Frey Marti 2010; Frey/Stutzer 2010; Stutzer/Frey 2010), when Layard argues that people are much happier where they have more rights to referendums and where direct democracy is established. But beside these parallels, the implications of Layard's work, which will be analysed in due course, include arguments which substantially deviate from Frey et al.

${ }^{21}$ Most of the international differences in the level of happiness are due to the following factors: unemployment and divorce rate, level of trust, membership in organisations, and quality of government (cp. Layard 2005/2011). ${ }^{22}$ Cp. Putnam's study Bowling Alone (Putnam 2000) as well as Putnam 1993a; 1993b; Coleman 1988; 1990.
} 


\subsection{Consequences for Economic Policy}

Before moving on to a general criticism of soft and hard paternalism, we need to come back to the self-defeating race for status so prevalent in modern-day societies (Layard 2005/2011: pp. 149). Here, the inherent dangers of the paternalistic state become obvious: According to Layard, a natural desire for status exists. But since the total amount of status in a society is pretty much fixed, this situation might be characterized as a zero-sum game (i.e., one person succeeds while others fail); it brings a long lots of negative externalities especially for those individuals that do not succeed. This race for status is self-defeating at the level of society as a whole. The struggle for relative income and position yields no social net gain. Even worse, it imposes external dis-benefits on others (having a negative effect on the happiness of those it puts pressure on), and involves distorted incentives: People work too hard in order to compete and keep up with the hedonic treadmill process. Private life and time with family and friends are massively sacrificed. As a result, the work-life balance is distorted causing mental diseases such as burnout, depressions and anxiety states, and the level of trust and social capital decreases within society, since the time for community activities shrinks to a minimum. Layard speaks of a 'physical pollution' which needs to be discouraged and here is where the state comes into the play. As Pigou (1920/1962) has shown, taxes provide a standard cure for pollution of all kinds. The state simply needs to charge people for the damage which they do to others and force them to reduce it. By introducing 'sin taxes' (i.e., 'pollution or addiction taxes') all external costs will be taken into account. As a consequence, the polluting activity will be cut back to the socially most efficient level. Therefore, Layard suggests that taxes should be implemented with regard to the hedonic treadmill problem. Taxes on income from socially inefficient work will reduce that kind of work. The tax functions as a corrective. It discourages behavior that is socially undesirable because it leads to a distorted work-life balance. Since taxes have a distorting effect on the struggle for status, they (ideally) help to preserve the work-life-balance and overcome the hedonic treadmill problem. It is like taxing addiction: People get used to higher wages and living standards. This leads to adaption as well as addiction. Because of this distorting effect of unforeseen habituation, the state has to tax unhealthy, addictive expenditures. ${ }^{23}$ Taxation, therefore,

\footnotetext{
${ }^{23}$ I.e., taxation as the solution to the addictive effects of income and spending: taxes discourage people from overwork and from running on a treadmill that brings less advantage in happiness than commonly expected.
} 
rectifies two forms of distortions, the one from pollution or negative externalities and the other one from unforeseen addiction. ${ }^{24}$

A further field of state interventionism is the growth of performance-related pay - also leading to an increase in stress and a distorted work-life balance. In addition, solely financial motives and incentives crowd-out intrinsic moral values. As Frey et al. have shown, external motivation will reduce internal motivation, and financial rewards will reduce people's willingness to act on the merits. ${ }^{25}$ One way to tackle this problem is to reduce (or even forbid?) performance-related pay. This also includes a fundamental reform of bonus payment systems.

Layard also wants to address the problem of advertisement. According to him, the sole purpose of ads is to change our value system and to make people want more. It has a negative effect on the level of happiness of those it puts pressure on, a pressure to succeed. In general, advertising lures people into an arms race ending up in a society obsessed by status. Its most serious effect is of course on children. Consequently, the state should ban all commercial advertising directed at children under the age of 12 (cp. Layard 2005/2011: pp. 160) and cut tax allowances for pictorial advertising to adults by business corporations.

Furthermore, Layard suggests the following measures which should be adopted by the state to increase individual as well as social well-being: first, high-quality child care education; second, compulsory parenting classes in school (Layard 2005/2011: pp. 176); third, familyfriendly practices at work including more flexible hours, more parental leave, easier access to child care, to name just a few. Moreover, he demands an education system that conveys the 'spirit of the public good' (cp. Layard 2005/ 2011: p. 200), i.e., an education policy that gives less value to status and more value to empathy, other-regarding preferences, and pro-social behavior. The aim of this school subject which should include courses in emotional intelligence as well as moral education is to produce a happier generation of adults, change the values of the youth culture, and produce more robust (i.e., inner strength) and virtuous

\footnotetext{
${ }^{24}$ Layard's position faces several serious drawbacks with which we will deal in the upcoming chapter. Among them are the following questions related to the just presented argument: What does it mean to be 'better off/ worse off objectively'? Which welfare criterion is applied? Who is in charge for deciding which forms of behavior are socially undesirable and unhealthy and which forms are socially acceptable? Which forms of behavior should be taxed and which ones shouldn't? Is it overall feasible to tax socially undesirable behavior? How can we practically measure negative external effects in this context? How does the implementation work in practice? Where does taxation start and are there any limits of taxation and state interventionism? How does the paternalistic state obtain the necessary knowledge required prior for making a decision between social desirability versus social undesirability? This argument seems to involve an elitist-expertocratic 'pretense of knowledge' and a form of social engineering criticized by Hayek, Popper, et al.

${ }^{25}$ Cp. Frey/Oberholzer-Gee/Eichenberger 1996; Frey/Oberholzer-Gee 1997; Frey/Jegen 2001; see also Titmuss 1970 and Sandel 2012.
} 
characters (i.e., happiness depends on the inner life of persons as much as on their outer circumstances).

In addition, a high-turnover community with its high level of anonymity has to be prevented due to its adverse social side-effects (i.e., weakening of families (increase in family breakups) and communities (increasing crime rates)). Consequently, Layard pleads for a restriction of geographical mobility. Finally, the state has to take more efforts to fight mental illnesses (Layard 2005/2011: 181ff.): According to Layard, depression and other psychological disorders cause much more misery than poverty. One way to achieve this is to promote the use of psychiatric drugs (Layard 2005/2011: 205ff.) in order to fight schizophrenia, manicdepression, panic attacks, phobias, obsessions and intense anxiety. The principal neurotransmitters that affect mental well-being are serotonine and dopamine (cp. Kosfeld et al. 2005). Once, we are familiar with the specific neurological mechanisms we can make use of happiness-enhancing drugs. Here, the dangers of abuse and manipulation - think of a 'personality change by pill' - become abundantly clear.

To sum up Layard's public policy recommendations (cp. Layard 2005/2011: pp. $223^{26}$ ): What is needed is a policy that fosters stable families (improving family life), communities (subsidising activities that promote community life) and family-friendly work-places, a policy that encourages trust and social capital, an education policy focusing on moral education, a policy that fights unemployment ${ }^{27}$, crime and mental illnesses as the greatest sources of misery in the industrialised world, a policy which discourages work efforts that make society worse off, a policy of far-reaching taxation in order to contain the race for status and preserve the work-life balance, and last not least, a policy of re-distribution aiming at helping the poor (including development $\mathrm{aid}^{28}$ and a more equal distribution of wealth and income in industrialised countries). The principle of greatest happiness is inherently pro-poor (Layard 2005/2011: pp. 120): it contains a strong argument in favour of redistribution in the sense that it is more important to reduce the suffering than to augment happiness.

\footnotetext{
${ }^{26}$ In concrete terms, Layard favors the following public policy recommendations: 1. Policy of financial redistribution; 2. Mental health (foster research, increase state expenditure, fight depressions and anxiety states); 3. Educational system (motto: implant the seeds of a happy life); 4. Parenting (bad parenting produces crime and unsocial behavior; thus, state intervention is legitimised; parenting should already be taught at school); 5 . Reduction of advertising (meant to change our tastes and intend to make people want more; ban of commercial advertisement for children required) and gambling (fight any form of addiction).

${ }^{27}$ Unemployment causes misery that goes far beyond the effect of losing income, because it breaks social ties and affects personal identity.

${ }^{28}$ I.e., an extra dollar gives more happiness to the poor than to the rich. Therefore, material redistribution and development aid are required.
} 
Layard admits that there are limits of state interventionism; especially when state interventions negatively affect people's freedom, they are illegitimate. A violation of liberty rights is one of the major causes of unhappiness. Thus, Layard warns of an over-intrusive state. The state should never violate individual freedoms. But, at the same time, he states that government exists to promote the happiness of people (Layard 2005/2011: pp. 256). Layard is convinced that there are some areas of public policy where the state could do much more in order to promote the well-being of people. The state should especially not hesitate to act on behalf of kids and other vulnerable groups, where the greatest happiness principle requires it this broadly defined state task leaves huge discretionary leeway for policy makers (and lobbying groups).

It is remarkable that Layard is explicitly in favour of 'libertarian paternalism'; yet, his actual policy recommendations clearly exceed those of libertarian paternalism. Thus, we use the term hard or strong paternalism to describe Layard's position (Layard 2005/2011: p. 271). His ideal state contains a clear rejection of laissez faire economics and minimal state-approaches; instead, it bears resemblances to a paternalist nanny state with all its inherent problems (i.e., danger of abuse, benevolent dictatorship, etc.). The next chapter will deal with these kinds of criticisms in more detail.

\subsection{Soft vs. Hard Paternalism}

It goes without saying that soft/libertarian paternalism promoted by economic psychologists (Kahneman) and behavioral economists (Thaler/Sunstein) and hard paternalism derived from (Layard's) happiness economics are different in at least one regard: While the former relies more on economic incentives and default rules (choice architecture) and clearly rejects authoritarian coercion and repression, the latter is much more intrusive in the sense of interfering with personal liberty and infringing on private autonomy (cp. Layard's ideas about education, parenting, and the use of medical drugs). Yet, the distinctions are subtle: A fluent or gradual transition from soft to hard paternalism exists. ${ }^{29}$ Layard, for example, is explicitly and positively referring to soft paternalism (cp. Layard 2005/2011: p. 271). From his perspective, both theories are complementing each other; no fundamental differences are detectable.

\footnotetext{
${ }^{29}$ Sunstein (2013a: p. 24/pp. 26) himself speaks of a continuum of paternalistic interventions from soft to hard paternalism and that the line between means and end paternalism can be blurry. He admits that there is simply no sharp or categorical line of distinction between the two. Moreover, hard/end paternalism is not ruled out completely by the proponent(s) of soft/libertarian paternalism. In some cases, hard/end paternalism can increase people's welfare and should therefore be applied (Sunstein 2013a: pp. 40).
} 
The problem with soft paternalism is that it is difficult to control and monitor. Once paternalistic interferences start, it is hard to stop. Where are the limits of soft paternalism? What is the optimal amount of (soft) paternalism? Which paternalistic policies are legitimate, which ones are illegitimate? ${ }^{30}$ In addition, soft paternalism is more subject to abuse (cp. Glaeser 2006) due to the fact that a huge discretionary leeway for legislative decision making exists and that paternalistic policies are based on a case-by-case interventionism (cp. chapter 4.4.). Finally, soft paternalism builds support for hard paternalism: Hard paternalism might appear as an attractive option for politicians seeking (re-)election as well as lobbying groups seeking rents and privileges. Paternalistic policies have redistributive effects and welfare implications; as such, they are more prone to the influence of special interest groups (cp. Schnellenbach 2011; 2012). Soft paternalism might be the start of a 'road to serfdom' - to use Hayek's terminology (Hayek 1944/2007); it might (inevitably?) lead to hard paternalism (cp. the slippery slope argument presented in chapter 4.4.). The points of criticism presented in this paper focus on Thaler/Sunstein and Kahneman showing that even softer versions of paternalism contain serious drawbacks and inherent dangers of abuse. These dangers, however, are even more pronounced in Layard's happiness economics. Therefore, all points of criticism below are much more relevant for Layard than for all other paternalists.

\section{The Challenges of Paternalist Economic Policies}

The rise of behavioral economics, economic psychology and economic happiness research goes along with an ever-increasing number of recommendations of paternalistic policies and government intrusion into the private sphere. The following paragraphs give an overview of the inherent dangers with regard to soft, libertarian, and hard paternalism.

\subsection{Idea of Man Argument}

Behavioral economists like Thaler/Sunstein and economic psychologists like Kahneman are convinced that paternalistic state interventions are required in order to overcome cognitive biases - as a further category of market failure; state interventions help people make better choices and ideally lead to an increase in social welfare. Since people cannot be trusted to make responsible choices based on their own subjective preferences due to their bounded

\footnotetext{
${ }^{30}$ That soft paternalism is hard to control shows the extension of scope in the 'Nugde'-book appendix as well as the various websites and 'nudge-policy-units' referring to the 'Nudge'-concept. Here the original concept is transferred to various areas including teenage pregnancy, smoking and drug addiction, gambling, donation and charity as well as no-bite nail polish and (e-mail) politeness checks. A wide range of soft paternalistic interventions is recommended. As such, the original concept goes far beyond the constitutional economics incentive structure and choice architecture. Even worse, Layard himself with his strong paternalistic economic policy recommendations explicitly refers to Thaler/Sunstein's 'Nudge'-concept.
} 
rationality, experts are required to make choices on behalf of the individual to prevent people from harming themselves or others. Moreover, choice architects function as social planners and social engineers designing society and prescribing actions of individuals from top-down rather than bottom-up. As such, the paternalistic trend towards greater government intrusion in the private sphere - often accompanied with a proliferation of new regulations, an increase in bureaucracy, and a rise of penalties and repression - goes along with a responsibility transfer from the individual to the state and a decline in democratic legitimacy; i.e., actions of individuals are paternalistically prescribed, values are heteronomously imposed upon individuals by the state, and experts decide what is best for society (i.e., elitist-expertocratic decision-making; cp. Saint-Paul 2011). ${ }^{31}$ As such, paternalism in all its facets (from Thaler/ Sunstein and Kahneman up to Layard) and with all its (slightly) illiberal and heteronomous tendencies is inconsistent with the liberal-Kantian idea of man based on private autonomy, sovereignty, emancipatory empowerment, and human dignity (cp. Kant 1974).

Paternalism is motivated and defended by the claim that the individual interfered with will be protected from harm or will be better off. It intends to produce good for an individual. From a Kantian perspective, however, paternalism has to be dismissed due its interference with liberty and infringement of private autonomy; the state interferes into the private sphere of individuals - often against their will. Limitations on personal autonomy or freedom are not acceptable. Denying individuals the right to make their own decisions implies treating them as simply as means and not as an end in themselves as the Kantian Categorical Imperative demands. The rational agency or personhood has always to be respected. From a Kantian perspective, there is hardly any legitimacy of state paternalism; especially, the argument which puts forward the fact that paternalism produces more good than harm is rejected due its consequentialism. ${ }^{32}$

In summary, the paternalistic (welfare) state is irreconcilable with the Kantian values of enlightenment, such as inalienable human rights and civil liberties. The enlightenment view of

\footnotetext{
${ }^{31}$ The former liberal state turns into a paternalistic nanny state (cp. Goodin 1991; Harsanyi 2007) or benevolent dictatorship. In doing so, the state's attitude towards its people changes dramatically: It might now be characterized as tutelage, patronage and infantilizing. The paternalistic state aims at parenting, nurturing and educating its people like a nanny or benevolent dictator. The state mistrusts its people to make the right decisions depriving them of their right of decision. Thereby, the risk of manipulation and abuse (i.e., violation of sovereignty, autonomy and other human rights) is omnipresent.

${ }^{32}$ The following questions come up: How should we deal with individual autonomy/liberty and its limits? How should we deal with the trade-off between a concern for the welfare of others, respecting their private sphere of autonomy, and the individuals' right to make their own decisions? Furthermore, are there any cases of justified paternalism imaginable; e.g., given that all agents would agree to such paternalistic interferences? If so, what are legitimate instruments for the state? Should it mainly rely on incentives or use coercive measures? Is the burden of proof necessarily on the state? These and other questions remain to be discussed in a further paper.
} 
man rests on rational, autonomous, self-conscious and (socially) responsible individuals within a democratically legitimate sociopolitical order. Accordingly, people are better informed about their own interests than others and know better than the state what is good for them. Thus, values should not be imposed upon individuals and actions should not be prescribed by an external authority like the state.

\subsection{Political Economy Argument}

Paternalistic policies assume that state solutions are under certain specific conditions better suited than market solutions. Based on the assumption that private decision-making is cognitively flawed, paternalism favours expertocratic and technocratic decision-making and state interventions. The state solution, however, faces several serious drawbacks compared to market solutions. These disadvantages are not properly taken into account by the various paternalistic concepts.

First, state solutions are inclined to be rather static and lack flexibility (also due to the fact that their feedback mechanisms are rather poor); they tend toward standardizations and a onesize-fits-all-policy ${ }^{33}$ which might be inappropriate in overcoming cognitive biases. The problem is that the heterogeneity of individuals and individual preferences are most often not taken into account by paternalistic planners. State solutions can also cause non-intended side effects which in turn might entail a spiral of interventions.

Second, the various paternalistic concepts do not take into account the phenomenon of state or government failure. The authors elaborate intensively on market failure - actually, this is one of the legitimizing reasons behind the different paternalism concepts -, but they almost completely neglect possible government failure. In general, their assumptions ask too much of politicians, state agencies and bureaucracies alike (i.e., overuse of the state). Even well-meant regulations and state interventions aiming at making the world a better place might backfire both because of the bounded rationality of politicians and bureaucrats and because of regulatory capture.

Third, Thaler, Sunstein, Kahneman and Layard seem to assume that government and state officials always pursue the common good. But can we really take their neutrality and disinterestedness for granted? How can we rule out bad intentions of choice architects, social engineers, government officials? How can we minimize the (potential) danger of abuse of power, and the risk of manipulation? If nudges might help to reach socially desirable goals -

\footnotetext{
${ }^{33}$ One way to avoid a one-size-fits-all approach is the introduction of personalized default rules, as suggested by Sunstein (2013c). This alternative, however, faces serious personal privacy and data security concerns.
} 
whatever that means -, they might also be employed to reach socially unwanted ones, e.g., choice architects and social designers could use their power to exploit and benefit from people's ignorance or lack of knowledge or they simply make use of subliminal advertising. Bad nudges are as likely as good ones! Moreover, another form of endangerment comes up, the danger of manipulation by lobbying and rent seeking-groups. The nudge-approach as well as Layard's strong paternalism grant a high discretionary leeway for the influence of special interest groups - even more so since the state's tasks and responsibilities as well as the possibilities for state interventionism are broadened and extended. Since paternalistic policies are mainly based on an ad hoc, arbitrary, and case-by-case interventionism basis (cp. chapter 4.4.), particularistic interest groups might exert a high pressure on the legislative decision making process. Is it overall feasible to restrict the power of lobbying groups and to set incentives for choice architects to always pursue the common good? It seems as if the authors of the various paternalism approaches underestimate the power relationships within the politico-economic context as well as the self-interested motives that might play a role for choice designers, that is bureaucrats and politicians. The central question here is: Can we always assume the neutrality and disinterestedness of choice architects as well as government officials? The principles of publicity and transparency in combination with adequate disclosure requirements should be adhered to. Control mechanisms and constitutional checks and balances are also required in order to rule out incompetencies and badly designed incentive architectures. Choice architects as well as the government in general have to pursue a politics which is publicly accountable and justifiable, and thus achieve public approval and acclaim. A transparent and comprehensible disclosure of the applied methods, the underlying motives - including a disclosure of potential conflicts of interests - and the pursued goals are needed.

So far, we have just dealt with the particular disadvantages of state solutions; now we turn to the (theoretical) advantages of markets. Here, the Hayekian and Buchanan' understanding of markets is of great help. Hayek (and Buchanan) view competitive markets as a 'spontaneous order' that allows for ongoing experiments, learning processes, and trial and error. Competition is regarded as a 'discovery procedure' that makes use of the division or fragmentation of widely dispersed and decentralized knowledge. ${ }^{34}$ Competitive markets and

\footnotetext{
${ }^{34}$ Cp. Buchanan 1975; Hayek 1968/2002; Schnellenbach 2011; 2012. According to Sugden (2008), the main argument of behavioral economics is that incoherent, unstable and context-dependent preferences, irrational consumers and bounded rationality justify paternalism. Yet, the existence of incoherent preferences does not touch upon the Hayekian or Buchanan' understanding of markets.
} 
the price mechanism enable a better, more accurate and faster feedback compared to public decision-making and state solutions. In politics, incentives to correct are rather weak and feedback mechanisms are rather poor. As a consequence, a greater error-proneness of state agencies compared with private decision-making exists: Public-political decision-makers or government bureaucrats make more errors on average than private decision makers (cp. Glaeser 2006). One reason is that the state solution (and not the market solution) faces the Hayekian knowledge problem: Paternalistic policies assume the perfectly informed paternalistic planner (i.e., 'pretence of knowledge' (Hayek 1974/ 1996)). The problem is that information on individual preferences cannot be centralized by a paternalistic government planner. In addition, paternalistic planners - just like ordinary people - face the problem of bounded rationality and realistic informational constraints (cp. the epistemological argument presented in section 4.3.). In practice, the lack of information impedes the design of efficiency-enhancing paternalist economic policies. Paternalist interventions aim to move the economy closer to its Pareto efficiency; they especially aim at Pareto improvements among consumers. Yet, this aim can hardly be reached due to informational constraints and bounded rationality of government bureaucrats; most often, the opposite of Pareto-optimality - i.e., socioeconomic inefficiencies - is 'achieved'. ${ }^{35}$ Schnellenbach (2012: p. 272; cp. 2011) concludes: “... all the biases leading to inferior decision-making identified by the new paternalists will be much stronger than on the market place, simply because immediate feedback mechanisms are missing." According to Schnellenbach et al., cognitive biases in politics are much more pronounced compared to those in the private or market sphere. Even worse, already existing biases can be even enhanced due to a much more indirect and unspecific feedback - the electoral competition in a parliamentary(!) democracy is rather rudimentary compared to everyday economic competition. Consequently, Schnellenbach favors entrepreneurship and market rewards instead of paternalism, and suggests markets for self-regulation and self-commitment a la Coase as a potential solution: More markets are needed instead of more government in order to overcome the cognitive biases of behavioural economics due to their superior knowledge transfer/exchange and better feedback mechanism.

\footnotetext{
${ }^{35}$ Paternalist state interventions also have to take their welfare effects/implications into account. Nudges and other paternalist instruments have redistributive effects not only for consumers, but also for shareholders and entrepreneurs. Moreover, they may imply welfare losses and negative external effects: They might be useful for one person, but negative for another. In addition, paternalist state interventions regarded as redistributive policies are more prone to the influence and abuse of lobbying groups (cp. Schnellenbach 2011; 2012).
} 


\subsection{Epistemological argument}

In the centre of soft or libertarian paternalism are the choice architecture and choice designers or social engineers. Especially, choice architects are responsible for nudging people to do the right thing or for influencing people in a certain way, a way that is presumably the best one for society as a whole. ${ }^{36}$ But what does it mean when we talk about the 'right thing', the 'right direction', and behavior that will 'most likely' and 'presumably' make the lives of individuals 'longer, healthier and better' (Thaler/Sunstein) or as in Layard's case 'happier'? What are desirable social objectives or target outcomes and how can we channel behavior in the right canals - once they are identified? How is it at all possible to gain and acquire such knowledge? How can we recognize and discern the required skills and information to make these kinds of (strategic) decisions? How can we assess and evaluate the impact of measures prior to adoption? How do we balance costs and benefits especially in cases where one section of the population gains while others have to bear the burdens? The various paternalism approaches (Thaler/Sunstein, Kahneman, and Layard) take for granted that the state as a benevolent dictator knows what is best for its citizens ${ }^{37}$; the state knows the direction we should head off and knows the appropriate instruments and measures that have to be taken on this way. A superior and almost omniscient knowledge is required to make such decisions. These kinds of assumptions are overtly unrealistic and presume 'pretence of knowledge'; i.e., required is the perfectly informed paternalistic planner. Even worse is the fact that this form of 'social engineering' (cp. Popper 1945/2011) rests on an elitist-expertocratic form of knowledge; i.e., experts - experts advising politicians and governments and experts in state bureaucracy - know best (elitist-expertocratic argument ${ }^{38}$ ), which is not only hard to achieve, but also self-contradictory. Especially Kahneman's work has shown that experts are famous for their unrealistic optimism and overconfidence often prone towards excessive risk-taking and other cognitive errors. The above-average effect is an excellent example illustrating overconfidence in practice. As such, expert judgments are anything but reliable sources for

\footnotetext{
${ }^{36}$ Paternalistic economics states that individuals themselves are not able to select the most efficient strategies and institutions due to their systematic cognitive biases. Thus, corrective regulation and government interference are required to correct the behavioural biases of market actors. In other words: paternalistic policies and government interventions in private transactions are legitimate to correct cognitive biases so as to converge to market efficiency or social optimization - so the argument goes. As such, behavioural economics is (mis-)used as a justification for greater government regulation of markets (cp. Saint-Paul 2011).

${ }^{37}$ Here, the following questions come up: How is it possible that an outsider or a person just standing on the sidelines knows what is best for the particular person in a particular situation or even for a nation as a whole? And in case that people cannot be trusted to make the right choices for themselves how can we trust other people, namely scientists, politicians or bureaucrats, to make the right choices for the rest of society?

38 A rational expert discourse is required. This kind of public will-formation, however, might be shaped by special interest groups as well as opinion leaders in the media.
} 
decision-making; scientific experts as well as government officials are prone to the same behavioral or cognitive biases as other humans. Authors like Saint Paul (2011) and Schnellenbach $(2011 ; 2012)$ are convinced that these biases are even greater in the government sector than in the private one, and that free and competitive markets have stronger and more reliable checks and balances than politics. Therefore, markets are wellsuited to solve behavioral and cognitive problems themselves; a need for enhanced state interventionism does not exist. Instead, what follows from behavioral economics, economic psychology as well as economic happiness research is that greater constitutional limits on governments - rules rather than discretion - are needed (cp. the Ordnungs- vs. Prozesspolitik argument below).

Finally, the rise of technocrats and paternalistic policies incorporates a further risk: In an expertocracy or technocracy, the level of discretion and secrecy increases tremendously and therefore the danger of abuse of power comes up again. Politics relying on experts are vulnerable to the influence of vested interests and lobbying groups. Moreover, it goes along with a lack of democratic legitimacy, since experts are seldom directly elected by the people.

\subsection{Constitutional Economics Argument ${ }^{39}$}

One of the strongest arguments against paternalist economic policies is the Ordnungs- vs. Prozesspolitik argument. The distinction between Ordnungs- and Prozesspolitik dates back to the origins of German Neoliberalism in the 1930ies. Ordnungspolitik is favoured, which means that the state as a legislator and rule-maker - and not as a major player - is responsible for setting, preserving and maintaining the regulatory framework; i.e., economic policies that institutionally frame in the sense of defining the general terms under which market transactions are carried out. In other words: the state has to focus solely on the rules of the game (procedure-oriented order of rules) instead of steering, influencing or intervening in market processes and the play itself (output-driven/results-oriented order of actions). The aim of (market-conform) Ordnungspolitik is to implement a socio-economic competitive order which is capable - as a means to an end - of safeguarding individual liberty as well as human dignity (together with the help of the rule of law). According to German Neoliberalism, the ideal state is a strong (i.e., powerful and efficient) and independent constitutional state, a state standing above special interest groups, and one that serves as a 'market police', as an ordering power and as a guardian of the competitive order. The state should be able to fend off

\footnotetext{
${ }^{39}$ Cp. Buchanan 1975; Vanberg 2004; 2005; 2008.
} 
particular interests, keep to the principle of neutrality and confine itself to Ordnungspolitik. The underlying liberal ideals are equality before the law, rule of law, freedom of privileges, and the principle of non-discrimination. Prozesspolitik by contrast is rejected for different reasons: Prozesspolitik as a form of 'privilege-granting policy' is based on isolated and ad hoc case-by-case decisions, it enables arbitrary and selective interventions in the economic 'game of catallaxy' (cp. Hayek 1973; 1976; 1979) - and what is most important - it is subject to the particularistic influence of rent seeking or special interest groups and their influence on the legislative process (this implies a high discretionary leeway for decision making and a lack of democratic legitimacy and control). This kind of interest groups based policy reduces the overall wealth of a nation (because of granting costly and exclusive privileges). Furthermore, it endangers and threatens the liberty of each individual. Following the neoliberal distinction between Ordnungs- and Prozesspolitik, all previously discussed forms of paternalism fall into the Prozesspolitik-category. These forms of paternalism rely on discretion rather than rules. A rule-based economic policy is absent. Instead, paternalistic policies mainly rely on case-bycase interventionism. Due to this lack of a long-term, sustainable, and stable economic policy, the discretionary leeway for decision making increases dramatically and thus opens the doors for particularistic interest groups. As a consequence, all forms of paternalism contain the previously mentioned dangers and risks - albeit to a differing degree in the sense that Layard's hard paternalism is much more exposed to the inherent dangers of paternalism than all other versions.

The Ordnungs- vs. Prozesspolitik argument is inextricably linked with the slippery slope argument: Soft paternalism may be the start of a 'road to serfdom' (Hayek); it is hard to stop or limit and it may (inevitably?) lead to hard paternalism. In other words: Once we allow the state to intervene in private affairs, we open the floodgates for even more state interventionism (i.e., spiral of interventionism) and tread the 'road to serfdom' drifting towards despotism (Hayek 1944/2007). In the end, the paternalistic intrusion of government in private affairs might lead to encompassing and extensive state control. We might end up in a centrally planned economy which will affect the political system as well; authoritarianism, despotism, and dictatorship in the political sector often accompany illiberalism in the economic sphere. It is hardly possible to distinguish between situations that require a little nudge and situations that require a proper push or even a hit by a public authority. As such, it is hard to distinguish between liberal interventions, interventions that go astray - and, thus, 
are the start of the slippery slope ${ }^{40}$ - and (slightly) authoritarian interventions. Furthermore, it seems difficult to impede the seemingly unstoppable process of increasing state interventionism. The danger of a potential overreaction (e.g., in the form of arbitrary or despotic abuse of power) appears on the stage and therefore, we have to nip things in the bud.

\subsection{Frey's Happiness Economics: An Alternative Paradigm?}

That it is feasible to derive an alternative approach with different policy recommendations from the new economic sub-disciplines shows the work of Frey and colleagues. ${ }^{41}$ Frey's argument is essentially Ordnungspolitik- and not Prozesspolitik-based focusing on the rules of the game (i.e., constitutional design) instead of intervening directly into the market transactions and the play itself. Frey's approach rests on participation, inclusion, and Teilhabe in the form of direct federal democracy. ${ }^{42}$

Frey claims that happiness depends to a large degree on personal, politico-economic freedom, rule of law, 'voice' and accountability. He found out that people are much happier where they have more rights to referendums and where direct-federal democratic institutions are implemented. The extent to which individuals are given 'voice' is essential; people have to have the feeling that they are treated with dignity, a feeling of inclusion, identity, and selfdetermination. Opportunities for citizens to participate are significant determinants of personal well-being. Living and acting under institutionalized processes which contribute to personal autonomy, self-legislation and citizen sovereignty increase happiness. The quality of the politico-economic process is a key factor in individual's happiness. In this regard, Frey distinguishes between procedural utility (i.e., utility derived from participating in socioeconomic and political decision making processes) and outcome utility (i.e., utility derived from the actual outcome of these decision making processes) (cp. Frey/Stutzer 2005):

\footnotetext{
${ }^{40}$ Saint-Paul (2011: pp. 78) summarizes the slippery slope argument as follows: Behavioral economics and economic happiness research start with awareness rising and educating people about their own cognitive biases; then, they aim at restricting choices for the people's own good (i.e., well-meant attempt to make the world a better place and to pursuit happiness) and a higher taxation for addictive goods ('sin taxes'); next comes pricing 'pseudo-externalities' and taxing to correct the drive for status. Even worse is manipulating the context by reframing the choice problem so as to favor the socially preferred and desirable outcome. In the end, behavioral economics and economic happiness research end up with manipulating beliefs and preferences by or through schooling, education and state propaganda: educational curricula are changed (for better or worse), people's access to information is restricted for their own good, and information is manipulated to improve social welfare. Core questions related to the slippery slope argument are: What is the optimal amount of paternalism (cp. Carlin et al. 2009)? Where are the limits of paternalism? Is it after all possible to limit paternalism to a clearly defined and restricted area of social/public policy? Do we - once paternalism is applied/ practiced - steadily and inevitably move from a liberal towards an authoritarian society in which people are deprived of their rights of decisions?

${ }^{41}$ Thus, the new economic sub-disciplines are not necessarily accompanied by a new, paternalistic style of politics; traditional policy recommendations can also be derived from the new disciplines.

${ }^{42}$ Cp. Frey 2010; Frey/Frey Marti 2010; Frey/Stutzer 2010; Stutzer/Frey 2010.
} 
Procedural utility is closely connected to the design of institutions. Frey's focus is thus on the macro level and the political constitution (cp. Frey/Stutzer 2000). Especially, two institutions affect happiness significantly: Federalism and direct democracy. Direct democracy gives people the opportunity to referenda, initiatives, and plebiscites. It establishes constitutional rules, checks and balances that function as safeguards against the rent seeking activities of particularistic interest groups. The pre-referendum (Habermas-like) discourse process with its exchange of arguments stimulates discussions among citizens and between politicians and citizens. It raises the level of information, the problem awareness of citizens and contributes to preference formation. Moreover, it ideally enhances citizen's perception of selfdetermination and lessens alienation and apathy. Empirical findings suggest that political decision making is closer to citizens' preferences in direct-democratic governance regimes: individual's preferences are better observed in political jurisdictions ${ }^{43}$ with more direct participation rights due to the fact that decision-making can be better monitored by the citizens. As a direct consequence, the actual outcomes are closer to popular preferences; thus, direct federal democracy raises not only procedural utility (in the sense of procedural fairness), but also outcome utility.

Furthermore, Frey's empirical studies on Switzerland show that direct-democratic and federal institutions raise the legitimacy of political action (which depends to a large degree on the voluntary agreement of the citizens involved) as well as the degree of social capital especially in the form of people's trust in governmental institutions: "The more extended the direct democratic rights are in a canton, the higher is tax morale, the lower are the tax burden and public deficits, the less citizens evade taxes, and the higher per-capita incomes are" (Frey 2010: p. 186). Direct democracy systematically raises procedural (and outcome) utility and therefore, increases subjective well-being and citizens' happiness. To put it differently: Direct participation possibilities increase the procedural utility produced for the voters which is an additional source of individual well-being. As a consequence, Frey pleads for encompassing individual's political-democratic participation rights, a decentralization of political decision making, federalism, subsidiarity, and local autonomy. Taken together, Frey's et al. approach not only avoids the inherent dangers of a paternalistic state, it also stands in the Kantian tradition taking the autonomy of people, human dignity and inalienable human rights seriously. It thus seems to be better suited for a modern version of Ordnungspolitik.

\footnotetext{
${ }^{43}$ So called Functional, Overlapping Competing Jurisdictions (FOCJ): cp. Frey 1997; Frey/Eichenberger 1999; Eichenberger/Frey 2002; Frey 2010: pp. 190.
} 


\section{Concluding Remarks}

The paper started with the thesis of a growing importance of paternalism within the theory of economic policy. This thesis was illustrated by referring to three different sub-disciplines within economics, namely behavioral economics, economic psychology and economic happiness research, all gaining momentum within the field of economics and all referring albeit to differing degrees - to the concept of paternalism. While behavioral economics and economic psychology tend to favor libertarian or soft paternalism, (Layard's) happiness economics legitimizes strong paternalism. Together with neuroeconomics (which bears lots of resemblances to the just mentioned disciplines ${ }^{44}$ ), these three respectively four disciplines are at the forefront of modern-day economics and are therefore of particular interest. In the centre of the paper were the works of Kahneman (as a representative of economic psychology), Thaler and Sunstein (as representatives of behavioral economics) and Layard (as a representative of economic happiness research). The way the paper was arranged - starting with Kahneman, Thaler and Sunstein and then moving on to Layard and economic happiness research - was not accidentally: Although the points of criticism mentioned in chapter 4 apply to all different versions of paternalism (soft, libertarian and Layard's hard paternalism), the inherent risks and dangers increase steadily and alarmingly and reach their "culmination point' in the work of Layard when he discusses the role of moral education as a means of a 'trans-valuation of values' (Nietzsche) and the use of medical (happiness-enhancing) drugs (pointing in the direction of cognitive enhancers or a 'Prozac nation'). Here, the dangers of abuse and the risks of manipulation manifest themselves. Not least neuroeconomics and here especially neuromarketing/-finance have shown how to (theoretically) tread a path towards a 'personality change by pill' (cp. Kosfeld et al. 2005). Moreover, such an approach opens the floodgate for unlimited state interventions and the creation of a nanny state in which the state acts as a benevolent dictator. The new findings of behavioral economics, economic psychology, and happiness economics as well as the inherent dangers and risks accompanying paternalistic policies have to be taken into account when debating a new or modern version of Ordnungspolitik - one that deals with the new forms of market failure (due to cognitive biases) as much as possible on the constitutional or regulatory ethics level (i.e., focusing on

\footnotetext{
${ }^{44}$ Neuroeconomics combines neuroscience, psychology, experimental and behavioral economics. Brain-imaging is regarded as a tool to develop new alternatives to the neoclassical paradigm of revealed preferences and expected utility theory, an aim shared with behavioral and experimental economics as well as economic happiness research; cp. Altman 2012: pp. 43; Damasio 2009; Glimcher et al. 2009.
} 
the rules of the game and the incentive architecture) without intervening too much into the private sphere of personal liberty and autonomy.

\section{References}

Akerlof, George/Dickens, William (1982): The Economic Consequences of Cognitive Dissonance; American Economic Review 72(3); 307-319.

Akerlof, George/Shiller, Robert (2009/2010): Animal Spirits. How human psychology drives the economy, and why it matters for global capitalism; Princeton, Princeton University Press.

Altman, Morris (2012): Behavioral Economics for Dummies; Mississauga, Wiley.

Buchanan, James M. (1975): The Limits of Liberty. Between Anarchy and Leviathan; Chicago, Chicago University Press.

Camerer, Colin/Issacharoff, Samuel/Loewenstein, George/O’Donoghue, Ted/Rabin, Matthew (2003): Regulation for Conservatives: Behavioral Economics and the Case for "Asymmetrical Paternalism"; University of Pennsylvania Law Review 151(3); 1211-1254.

Carlin, Bruce Ian/Gervais, Simon/Manso, Gustavo (2009): When Does Libertarian Paternalism Work? Cambridge; Working Paper of the National Bureau of Economic Research No. 15139.

Coleman, James S. (1988): Social Capital in the Creation of Human Capital; American Journal of Sociology Vol. 94 Issue Supplement: Organizations and Institutions: Sociological and Economic Approaches to the Analysis of Social Structure; S95-S120.

- (1990): Foundations of Social Theory; Cambridge, Harvard University Press.

Damasio, Antonio (2009): Neuroscience and the Emergence of Neuroeconomics in: Glimcher/Camerer/Fehr/ Poldrack (eds.): Neuroeconomics. Decision Making and the Brain; Amsterdam, Elsevier; 209-213.

Easterlin, Richard A. (1995): Will raising the incomes of all increase the happiness of all? Journal of Economic Behavior and Organization 27; 35-47.

Eichenberger, Reiner/Frey, Bruno S. (2002): Democratic Governance for a Globalized World; Kyklos 55(2); 265-287.

Frey, Bruno S. (1997): Ein neuer Föderalismus für Europa: Die Idee der FOCJ; Tübingen, Mohr Siebeck.

- (2010): Happiness. A Revolution in Economics; Cambridge, MIT Press.

Frey, Bruno S./Eichenberger, Reiner (1999): The New Democratic Federalism for Europe: Functional, Overlapping and Competing Jurisdictions; Cheltenham, Edward Elgar.

Frey, Bruno S./Frey Marti, Claudia (2010): Glück. Die Sicht der Ökonomie; Zürich, Rüegger. Frey, Bruno S./Jegen, Reto (2001): Motivation Crowding Theory; Journal of Economic Surveys 15(5); 589-611.

Frey, Bruno S./Oberholzer-Gee, Felix (1997): The Cost of Price Incentives: An Empirical Analysis of Motivation Crowding-Out; American Economic Review 87(4); 746-755.

Frey, Bruno/Oberholzer-Gee, Felix/Eichenberger, Reiner (1996): The Old Lady Visits Your Backyard: A Tale of Morals and Markets; Journal of Political Economy 104(6); 1297-1313.

Frey, Bruno S./Stutzer, Alois (2000): Happiness, Economy and Institutions; Economic Journal 110(466); 918-938.

Frey, Bruno S./Stutzer, Alois (2005): Beyond Outcomes: Measuring Procedural Utility; Oxford Economic Papers 57; 90-111.

Frey, Bruno S./Stutzer, Alois (2010): Happiness and Economic Policy; CESifo; 3-7.

Glaeser, Edward (2006): Paternalism and Psychology; University of Chicago Law Review 73; 133-156. 
Glimcher, Paul W./Camerer, Colin F./Fehr, Ernst/Poldrack, Russell A. (2009): Introduction: A Brief History of Neuroeconomics in: Glimcher/Camerer/Fehr/Poldrack (eds.): Neuroeconomics. Decision Making and the Brain; Amsterdam, Elsevier; 1-12.

Goodin, Robert Edward (1991): Permissible Paternalism: In Defense of the Nanny State, The Responsive Community 1; 42-51.

Haidt, Jonathan (2001): The Emotional Dog and Its Rational Tail: A Social Intuitionist Approach to Moral Judgment; Psychological Review 108(4); 814-834.

Harsanyi, David (2007): Nanny State; New York, Broadway Books.

Hayek, Friedrich August von (1944/2007): The Road to Serfdom; Chicago, Chicago University Press.

- (1968/2002): Competition as a Discovery Procedure; Quarterly Journal of Austrian Economics 5(3); 9-23.

- (1973): Law, Legislation and Liberty. A new statement of the liberal principles of justice and political economy Vol. 1: Rules and Order; London, Routledge.

- (1974/1996): Die Anmaßung von Wissen (Pretence of Knowledge) in: Kerber, Wolfgang (ed.): Die Anmaßung von Wissen; Tübingen, Mohr Siebeck; 3-15.

- (1976): Law, Legislation and Liberty Vol. 2. The Mirage of Social Justice; London, Routledge.

- (1979): Law, Legislation and Liberty Vol. 3: The Political Order of a Free People; London, Routledge.

Kahneman, Daniel (2011): Thinking, fast and slow; London, Allen Lane.

Kahneman, Daniel/Tversky, Amos (1972): Subjective Probability: A Judgment of Representativeness; Cognitive Psychology 3; 430-454.

Kahneman, Daniel/Tversky, Amos (1974): Judgment under Uncertainty: Heuristics and Biases; Science 185(4157); 1124-1131.

Kahneman, Daniel/Tversky, Amos (1979): Prospect Theory: An Analysis of Decision under Risk; Econometrica 47; 313-327.

Kahneman, Daniel/Tversky, Amos (1984): Choices, Values, and Frames; American Psychologist 39(4); 341-350.

Kahneman, Daniel/Tversky, Amos (1986): Rational Choice and the Framing of Decisions; Journal of Business 59(4); S251-S278.

Kahneman, Daniel/Tversky, Amos (1996): On the Reality of Cognitive Illusions; Psychological Review 103(3); 582-591.

Kant, Immanuel (1974): Kritik der praktischen Vernunft. Grundlegung zur Metaphysik der Sitten; Frankfurt, Suhrkamp.

Keynes, John Maynard (1936/1973): The General Theory of Employment, Interest and Money; London, Macmillan.

Kosfeld, Michael/Heinrichs, Markus/Zak, Paul J./Fischbacher, Urs/Fehr, Ernst (2005): Oxytocin increases trust in humans; Nature 435; 673-676.

Layard, Richard (2005/2011): Happiness. Lessons from a New Science; London, Penguin.

- (2010): The Greatest Happiness Principle: Its Time has come; CESifo; 26-31.

Loewenstein, George/Haisley, Emily (2008): The Economist as Therapist: Methodological Ramifications of 'Light' Paternalism in: Caplin, Andrew/Schotter, Andrew (eds.): The Foundations of Positive and Normative Economics. A Handbook; Oxford, Oxford University Press; 210-245.

Malmendier, Ulrike/Tate, Geoffrey (2005a): CEO Overconfidence and Corporate Investment; Journal of Finance 60(6); 2661-2700. 
Malmendier, Ulrike/Tate, Geoffrey (2005b): Does Overconfidence Affect Corporate Investment? CEO Overconfidence Measures Revisited; European Financial Management 11(5); 649-659.

Malmendier, Ulrike/Tate, Geoffrey (2008): Who Makes Acquisitions? CEO Overconfidence and the Market's Reaction; Journal of Financial Economics 89(1); 20-43.

Malmendier, Ulrike/Tate, Geoffrey (2009): Superstar CEOs; Quarterly Journal of Economics 124(4); 1593-1638.

Malmendier, Ulrike/Güner, Burak/Tate, Geoffrey (2008): Financial Expertise of Directors; Journal of Financial Economics 88(2); 323-354.

Mises, Ludwig von (1922): Die Gemeinwirtschaft. Untersuchungen über den Sozialismus; Jena, Fischer.

- (1927): Liberalismus; Jena, Fischer.

Nozick, Robert (1991): Anarchy. State. Utopia; Oxford, Blackwell.

O'Donoghue, Ted/Rabin, Matthew (2003): Studying Optimal Paternalism. Illustrated by a Model of Sin Taxes; American Economic Review 93(2); 186-191.

Pigou, Arthur Cecil (1920/1962): The Economics of Welfare; London, Macmillan.

Putnam, Robert D. (1993a): Making Democracy Work. Civic Traditions in Modern Italy; Princeton, Princeton University Press.

- (1993b): The Prosperous Community - Social Capital and Public Life; American Prospect $13 ; 35-42$.

- (2000): Bowling Alone. The collapse and revival of American community; New York, Simon \& Schuster.

Popper, Karl R. (1945/2011): The Open Society and Its Enemies; Abingdon, Routledge.

Rothbard, Murray N. (1962/2010): Man, Economy, and State. A Treatise on Economic Principles; Whitefish, Kessinger Publishing.

- (1982/2003): The Ethics of Liberty; New York, New York University Press.

Saint-Paul, Gilles (2011): The Tyranny of Utility. Behavioral Social Science and the Rise of Paternalism; Princeton, Princeton University Press.

Samuelson, William/Zeckhauser, Richard (1988): Status Quo Bias in Decision Making; Journal of Risk and Uncertainty 1; 7-59.

Sandel, Michael J. (2012): What Money can't buy. The Moral Limits of Markets; New York, Farrar.

Schnellenbach, Jan (2011): Wohlwollendes Anschubsen: Was ist mit liberalem Paternalismus $\mathrm{zu}$ erreichen und was sind seine Nebenwirkungen?; Perspektiven der Wirtschaftspolitik 12(4); 445-459.

- (2012): Nudges and Norms: On the political economy of soft paternalism; European Journal of Political Economy 28; 266-277.

Simon, Herbert A. (1957): A Behavioral Model of Rational Choice in: Models of Man, Social and Rational: Mathematical Essays on Rational Human Behavior in a Social Setting; New York, Wiley.

- (1959): Theories of Decision-Making in Economic and Behavioral Science; American Economic Review 49(3); 253-283.

- (1990): A Mechanism for Social Selection and Successful Altruism; Science 250(4988); $1665-8$.

- (1991): Bounded Rationality and Organizational Learning; Organization Science 2(1); 125 134.

Sunstein, Cass (2013a): Behavioral Economics and Paternalism; Yale Law Journal 122; 1-60.

- (2013b): Simpler. The Future of Government; New York, Simon \& Schuster. 
- (2013c): Impersonal Default Rules vs. Active Choices vs. Personalized Default Rules: A Triptych; available at: http://ssrn.com/abstract=2171343 (accessed: 11 July 2013).

Stutzer, Alois/Frey, Bruno S. (2010): Happiness and Political Institutions; CESifo; 32-36.

Sugden, Robert (2008): Why incoherent preferences do not justify paternalism; Constitutional Political Economy 19; 226-248.

Thaler, Richard H./Sunstein, Cass R. (2003a): Libertarian Paternalism; American Economic Review 93(2); 175-179.

Thaler, Richard H./Sunstein, Cass R. (2003b): Libertarian Paternalism is not an Oxymoron; University of Chicago Law Review 70(4); 1159-1202.

Thaler, Richard H./Sunstein, Cass R. (2008/2009): Nudge. Improving Decisions About Health, Wealth, and Happiness; London, Penguin.

Titmuss, Richard M. (1970): The Gift Relationship. From Human Blood to Social Policy; London, George Allen \& Unwin.

Tversky, Amos/Kahneman, Daniel (1971): Belief in the Law of Small Numbers; Psychological Bulletin 76; 105-110.

Tversky, Amos/Kahneman, Daniel (1980): Causal Schemas in Judgments Under Uncertainty in: Fishbein, M. (ed.): Progress in Social Psychology; Hillsdale, Erlbaum.

Tversky, Amos/Kahneman, Daniel (1983): Extensional vs. Intuitive Reasoning: The Conjunction Fallacy in Probability Judgment; Psychological Review 91; 293-315.

Tversky, Amos/Kahneman, Daniel (1992): Advances in Prospect Theory: Cumulative Representation of Uncertainty; Journal of Risk and Uncertainty 5; 297-323.

Vanberg, Viktor (2004): The Freiburg School: Walter Eucken and Ordoliberalism; available at: www.eucken.de/publikationen/04_11bw.pdf (accessed: 11 July 2010).

- (2005): Market and state: the perspective of constitutional political economy; Journal of Institutional Economics 1(1); 23-49.

- (2008): Wettbewerb und Regelordnung; Tübingen, Mohr Siebeck.

Weimann, Joachim/Knabe, Andreas/Schöb, Ronnie (2012): Geld macht doch glücklich. Wo die ökonomische Glücksforschung irrt; Stuttgart, Schäffer-Poeschel. 